\title{
Green Growth in cities: two Australian cases
}

\author{
Tania Urmee*, Martin Anda, Anna Chapman, and Md. Anisuzzaman \\ School of Engineering and Information Technology, Murdoch University, Perth, Australia
}

Received: 28 April 2017 / Received in final form: 16 July 2017 / Accepted: 27 July 2017

\begin{abstract}
Green Growth (GG) is about decoupling emission intensity from economic growth, which can be achieved by fostering positive economic growth through resource-efficiency, cleaner environment and increased resilience to climate change. Cities play an important role in economic development, as they are inhabited by a large proportion of the global population in a relatively small land area and cities are the wheel of the economy of a country. Implementation and measurement of GG in cities is challenging as the regulatory framework, roles and responsibilities to the citizen and the encompassing environment of cities differ significantly. This can be addressed by identifying a set of GG indicators that are relevant to target cities, which would be used by the cities to implement programs and policies, and to measure progress and performance. Australia is situated in an environment somewhat disconnected from the rest of the world, which is home to unique biodiversity and vulnerable ecosystems. The regulatory and institutional framework of Australian cities is different to many other cities in the world in terms of their obligations to the community and the environment, and the level of law enforcement, particularly in areas that are relevant for GG. This paper reviews the available GG indicators in cities and assesses the applicability of those indicators against the regulatory and institutional framework of Australian cities. The application of the proposed set of indicators to the City of Melbourne and the City of Perth helped to validate the appropriateness of those indicators and to assess the performance of the cities in relation to GG. It appears that the cities are performing well in some areas and need improvement in others. The cities also need to mainstream the GG indicators and to align their data measurement and recording systems in line with the proposed GG indicators.
\end{abstract}

\section{Introduction}

The core concept of Green Growth (GG) is to maintain a positive economic growth while reducing emissions and energy intensity of productivity through sustainable and efficient use of the natural asset base. This can bring multiple co-benefits, including cleaner environment, more jobs and investments; and improvement in human wellbeing. While there are differences in definitions of GG, developed by the development agencies, generally they refer to economic growth that not only preserves but enhances the natural resources we have inherited. GG is not a new paradigm, instead it is an operational strategy to implement the sustainable development paradigm which is "growth that is forceful and at the same time socially and environmentally sustainable" [1].

Cities play an important role in economic development, as they provide economies of scale, efficient infrastructure and services through density and concentration in transportation, communications, power, human interactions, and enabling environment for trade [2]. Over

\footnotetext{
* e-mail: t.urmee@murdoch.edu.au
}

3.3 billion people are living in urban areas and this is expected to expand to become 5 billion by 2030 [3]. Cities, as aggregates of human activities, require energy in a variety of forms. Much of the primary energy sources transformed to be available to most of the cities around the world are still fossil-based, resulting in global climate change [4]. The largest cities of the Organisation for Economic Co-operation and Development (OECD) that constitute about $2.4 \%$ of OECD regions, generate about $27 \%$ of all growth of the region [5]. While this trend would differ in other regions, the urban area would still dominate in the national growth in most countries, mainly due to their high productivity and income. Given the enormous role of cities in economic development and housing a large population, it is vital that the growth is decoupled from the energy and emission intensity. There are various green GG frameworks and sets of indicators available from different organisations; however, most are for national level. In addition, unlike the national level regulatory and institutional frameworks, these vary widely at city levels from one country to the other. Therefore, GG indicators for cities need to be customised to suit the local context, and also should be measurable at the local level. This 
paper proposes a set of indicators that are applicable to Australian cities, which would be useful for the city planners to implement GG in cities. First, it reviews the available GG indicators for cities and assesses them in the context of the regulatory and institutional frameworks of Australian cities. Then it validates the applicability of those indicators by applying to two Australian capital cities - the City of Melbourne and City of Perth. The performance of these cities in line with the proposed GG indicators is also assessed. Finally, recommendations are made to further improve the GG measures in Australian cities.

\section{Indicators to measure Green Growth in cities}

\subsection{Overview of Green Growth indicators in cities}

Development of a unique GG framework that fits all cities is a big challenge, as it poses a number of methodological limitations. Firstly, the administrative size of cities tend to vary widely, and the administrative and governance structure of cities is highly heterogeneous within and between countries [5]. These differences lead to variation in the way and the extent of urbanisation takes place, as well as the socio-economic and environmental impact that the city would be facing[5]. Secondly, the regulatory and institutional frameworks of cities vary widely from one country to the other. Thirdly, the indicators need to be comparable across cities within a country as well as with international cities. Due to these difficulties, the OECD suggests a new set of GG indicators, which is different from the national level indicators. To develop city level GG indicators that are comparable across cities and countries within the European Union, the OECD relied on the available international databases that record data to measure the environmental performances of cities. These 80 indicators have been grouped into nine thematic areas land use, urban air, water use, urban water quality, waste management, transport and traffic, climate change and energy, and environmental health [5].

The OECD has also proposed to include economic indicators (e.g. Gross Domestic Product (GDP) and GDP growth) and social indicators (e.g. unemployment and crime rate) to ensure that the indicator set responds to all dimensions of sustainability and appropriately aligns with the key concept of GG i.e. fostering economic growth and development through the sustainable and efficient use of natural asset base [6]. The OECD affirms that the cities do not need to use all 80 indicators to measure the performance of GG rather they need to select the ones that are relevant for them, mainly based on the availability of data and that fall within their jurisdiction. Also, the indicators may need to be adjusted, keeping the thematic area the same, to suit their local condition. This is due to the fact that not all cities have the same regulatory framework to control, measure and enforce the GG indicators. In the next section, we provide a brief review of the diverse range of GG indicators that have been used in different cities worldwide.

\subsection{Review of indicators for Green Growth in cities}

Cities are seen to have customized the GG indicators based on their measurability as well as implementation ability. Following are a few examples of GG best practices, grouped into indicator categories, which have been implemented in different cities worldwide. The applicability of those indicators in the context of Australian cities is also discussed.

\subsubsection{Built environment indicators}

The OECD suggests a set of indicators under the "Land Use" theme, which include, for example, extent of built-up area, share of new development in built areas, density of city region (measured by resident population per $\mathrm{km}^{2}$ ), percentage of population living within $300 \mathrm{~m}$ of green space, proportion of city brownfield sites that has been redeveloped, and area of land protected from urban development. Stockholm assesses the city's population growth, and housing growth [7]. Kitakyushu has indicators based on densification through urban planning, measured by population growth, and brownfield redevelopment [8]. These indicators are mostly relevant for the Australian cities, as they have regulatory authority in planning the land use (built up area) of their cities. The type of data and information are commonly measured and recorded include number of green buildings, area of green infill, number of people living in per $\mathrm{km}^{2}$, proximity of critical amenities to residents, connectivity to the transport system, which can be measured by vehicle kilometre travelled (VKT).

\subsubsection{Climate and energy indicator}

Stockholm measures the performance of industry clusters such as green technologies, residential building energy consumption rate (which indicates market potential) and green patent applications [7]. Korea has an objective to develop green technologies measured through an increased share of Korean green technology firms and green technology foreign experts [9]. The Ile-de-France region indicators focus on green sector growth within the building sector (heating, air conditioning, insulation) and increases in job creation in these areas [10]. Australian cities are aiming to increase the implementation of green technologies to increase energy resilience and reduce GHG emissions. For example, the City of Sydney (the capital city of New South Wales) has implemented tri-generation technology to reduce their carbon emissions from the Town Hall House [11]. City of Perth (the capital city of Western Australia) is committed to reduce energy consumption, be more sustainable and use renewable energy technologies where possible [12].

\subsubsection{Biophilia (urban greenery) indicators}

Biophilia refers to the hypothesis that humans possess an innate tendency to connect themselves to the natural and other forms of life [13]. The concept has also been applied to the design of built environment and cities. As GG focuses on the sustainable use of natural resources and improving human well-being, the biophilic city concept can be seen as 
an integral characteristic of GG in cites. Biophilic city design has many co-benefits, including the reduction of urban heat island (UHI) effect. Singapore has successfully demonstrated that planning regulations and planning strategies for biophilic urbanism can be delivered cost effectively and mainstreamed into the economic development plan [14]. Cities in Australia also have taken several initiatives to increase green space and safeguard urban ecosystems in an attempt to improve community wellbeing through biophilic urban design. The City of Melbourne (CoM) has promoted the idea of "city in a forest" [15].

\subsubsection{Transport and traffic indicators}

Measurable examples of transport indicators include the share of cars per capita and growth rate, ozone levels, hybrid and EVs, use of cars compared to the population growth, levels of public transport, bicycle use and walking [7]. Korea measures the rail users, cycling and urban passenger transport levels [16]. Kitakyushu transport indicators feature public transport levels, walking, bike levels, and residential proximity to public transport [8]. The OECD suggests a range of indicators under the transport and traffic theme, such as urban traffic intensity (measured by VKT), share of city trips by motorists, number of people commuting in/out of the city as a share of population, city road network length $(\mathrm{km} /$ capita), proximity of transport (measured as percentage of residents living within $500 \mathrm{~m}$ of transport connection), length of bicycle path, and household expenditure on transport services. Australian cities are heavily focusing on improving the transport services and traffic management to reduce the use of personal vehicles on the road. The City of Perth (CoP) integrated transport strategy aims to ensure the city's transport systems contribute to a sustainable, productive, liveable and vibrant city [17]. The types of measurable indicators that would suit the Australian cities include the level of investments made in transport sector, number of transport jobs created, number of people using public transport, VKT and the reduction in transport related emissions.

\subsubsection{Waste indicators}

The OECD document looks at recycling levels, landfill rates and percentage of household waste as indicators for GG [7]. The Paris/IDF Ile-de-France report assesses the recovery and sorting employment rates and growth [10]. The Kitakyushu GG document looks at waste indicators relating to the reduction in household waste, landfill rates, increase in waste recycling through the "Kitakyushu Fundamental Plan for Establishing a Resource-Circulation Society" [8]. The regulatory and institutional frameworks of Australian cities require the cities to collect and manage wastes from residential and commercial sectors, excludes industrial waste. The administrative roles and responsibilities of waste management are very similar across all cities in Australia. The types of information and data recorded in this regard include amount of waste collected, recycled and recovered; amount of waste reduced through community awareness; amount of illegally dumped waste (if any) reduced; and waste related emissions reduced.

\subsubsection{Water indicators}

The OECD has suggested a range of water indicators covering both "water use" and "urban water quality". These include industrial water use intensity by sub-sector, domestic water consumption, drinking water quality standards, grey water systems in households/buildings, urban waste water treatment policy, percentage of population connected to water supply, percentage of population connected to sewerage system, and population connected to urban wastewater treatment plants [5]. Some of these indicators do not have much relevance for Australian cities. For example, the cities do not have regulatory power to enforce water measures in industries. Therefore, indicators like investment in water infrastructure, water related job creation, water quality and water use reduction would be relevant for Australian cities.

\subsubsection{Economic growth indicators}

Economic growth indicator refers to the growth in economic activities, which can be measured by various parameters, such as increase in employment, investment, net export value, etc. For example, one of Stockholm's indicators is for a "diverse, service-based and knowledgeintensive economy" [7]. This is measurable by assessing, for example, the city's contribution to the national GDP or the city level GDP growth [7]. Kitakyushu measures the share of services and manufacturing in the Kitakyushu's economy, suggesting a declining manufacturing and growth in services indicates GG, through offering "higher value-added activities" and can improve productivity, while often being less energy intensive and thus helping to reduce greenhouse gas emissions [8]. While there is a wide variation of how economic growth in a city has been measured, the use of the city level GDP (in dollar term) and the city's GDP as a share of national GDP (in percentage) can be used widely due to the availability of city level data, including for Australian cities [18].

Based on the above observations and discussions a set of indicators for Australian cities are proposed in Table 1. The choice of these indicators has been based on the regulatory and institutional frameworks of Australian cities and the commonly measured and recorded data at city level.

\section{Greening growth in Australian cities - case studies}

Nearly two thirds $(64 \%)$ of the population of Australia reside in the eight capital cities [19] and these cities are expecting a surge in population. Therefore, the benefits of GG policies in cities will affect a large percentage of Australian residents. We study the case of two capital cities in Australia - the City of Perth $(\mathrm{CoP})$ and City of Melbourne (CoM), to first assess the applicability of the proposed set of indicators (Tab. 1) and then to assess how 
Table 1. Proposed Green Growth indicators for Australian cities.

\begin{tabular}{|c|c|c|}
\hline Indicator category & GG indicator & Unit of measurement \\
\hline \multirow{3}{*}{ Built form } & Green buildings, green infill & Sqm floor area \\
\hline & People in high density and infill & $\#$ people per $\mathrm{km}^{2}$ \\
\hline & Proximity to critical amenities & Reduction in VKT \\
\hline \multirow{3}{*}{$\begin{array}{l}\text { Climate change } \\
\text { and energy }\end{array}$} & Renewable kWh generated & Growth in $\mathrm{kWh}$ generated \\
\hline & $\begin{array}{l}\text { Energy emissions abated, energy } \\
\text { consumption reduced }\end{array}$ & $\begin{array}{l}\mathrm{tCO}_{2} \text {-e abated, per capita } \mathrm{kWh} \\
\text { consumption reduced }\end{array}$ \\
\hline & Increased green space, urban forestry & Forest cover as $\%$ of the city land area \\
\hline \multirow[t]{3}{*}{$\begin{array}{l}\text { Biophilia } \\
\text { (urban greenery) }\end{array}$} & $\begin{array}{l}\text { Increased community participation, health, } \\
\text { wellbeing, green jobs }\end{array}$ & \# people with improved well-being \\
\hline & Reduced urban heat island effect & Changes in mean temperature $\left({ }^{\circ} \mathrm{C}\right)$ \\
\hline & $\begin{array}{l}\text { Investment in public transport } \\
\text { system }+ \text { job creation }\end{array}$ & $\begin{array}{l}\$ \text { value of investment }+\# \text { transport } \\
\text { jobs created }\end{array}$ \\
\hline \multirow[t]{3}{*}{ Transport } & $\begin{array}{l}\text { Use of public transport system } \\
\text { and Use of active transport }\end{array}$ & \# people using public transport $+\mathrm{VKT}$ \\
\hline & Transport emissions abated & $\mathrm{tCO}_{2}$-e abated \\
\hline & $\begin{array}{l}\text { Investment in infrastructure } \\
\text { and creation of jobs }\end{array}$ & $\$$ value of investment $+\#$ water jobs created \\
\hline \multirow[t]{3}{*}{ Water } & Access to clean water & \# people with access \\
\hline & Quality of water & Concentration of water pollutants $\mathrm{mg} / \mathrm{L}$ \\
\hline & $\begin{array}{l}\text { Reduced waste generation, } \\
\text { reduced landfill }\end{array}$ & \# tonnes reduced \\
\hline \multirow[t]{2}{*}{ Waste } & Cleaner (waste free) environment & \# tonnes waste removed from illegal dumping \\
\hline & $\begin{array}{l}\text { Safe disposal/processing of waste, } \\
\text { reduced illegal dumping }\end{array}$ & \# tonnes recycled \\
\hline \multirow{2}{*}{ Economic growth } & $\begin{array}{l}\text { City level GDP and city's GDP as a } \\
\text { share of national GDP }\end{array}$ & GDP (in dollars) and GDP share (in \%) \\
\hline & Carbon intensity of GDP & tCO2-e as per unit of GDP \\
\hline
\end{tabular}

these cities are performing in accordance with the selected indicators. The choice of capital cities is mainly due to the fact that they have local government authorities (LGAs) for their central city areas that have a higher level of regulatory and administrative capability than the suburban and rural LGAs.

\subsection{City of Perth (CoP)}

The CoP is a local government within the Perth metropolitan area and is the capital of Western Australia, which is home to 2.6 million people and attracts an estimated 2.2 million visitors annually from interstate and overseas. CoP has an area of about $14 \mathrm{~km}^{2}$, the Central Business District (CBD) and an estimated population of 24,000 as of 2016 . The city is rapidly growing in both population and economic prosperity and its economy is highly reliant on its world-class reserves of natural mineral and energy resources. By 2050, the population of the city is expected to more than double to 50,000 people. The remarkable economic growth of the city has led to a number of large-scale capital works projects throughout the city and surrounding areas, which is expected to attract more investors, and in turn will lead to further economic growth. The city generates $26 \%$ ( $\$ 41.8$ billion) of greater Perth's
Regional Product (GDP) and contains 5.6 million $\mathrm{m}^{2}$ of business and institutional floor space. It has 14,000 registered businesses providing 134,500 employments [20]. GHG emissions of the city were 0.91 million tCO2-e in 2015 , with the majority (63\%) of this from energy use in buildings followed by transportation $(32 \%)$. The environment strategy (adopted in March 2016) measures a range of operational targets under the designated focus areas of "environmental sustainability and health", "climate response", "energy resilience", "water sensitive city", and "waste conscious city"[21]. The Cycle Plan 2029 aims to create a cycle network and actively promoting the use of bikes [22] and the Urban Forest Plan [23] focuses on increasing the biophilia in the city.

\subsection{City of Melbourne (CoM)}

The CoM is a local government and host of the CBD of Melbourne. The municipality covers $37.7 \mathrm{~km}^{2}$. It is made up of the city centre and a number of inner suburbs, each with its own distinctive character and with different businesses, dwellings and communities living and working there. The population of the CoM was 128,000 and the current population of greater Melbourne is 4.5 million [24]. Public Transport contributes to $60 \%$ (552.6 ktCO2-e) to the city's 
GHG emissions [25]. The CoM has planned to source $25 \%$ of electricity consumption in the municipality from renewable sources by $2018[26]$. This will be achieved through a combination of Federal and State policies (such as the Renewable Energy Target), local rooftop solar, and additional voluntary purchasing of renewably generated electricity through the grid. There are 455,753 jobs in the municipality, 7.95 million $\mathrm{m}^{2}$ office space and 1.55 million $\mathrm{m}^{2}$ retail space [27]. In the CoM, existing buildings contributes over $50 \%$ of carbon emissions. The city has a target to achieve zero emission city by 2020 . To achieve the target, the city aims to reduce its emission by $10 \%$ compared to the $2010-11$ baseline year by the year 2018. It also plans to achieve further emission reductions to meet its target.

\subsection{Built form}

The CoP is a growing city and therefore, it is currently undergoing massive development works - such as the construction of new buildings, civic facilities and large floor spaces. However, the city aims to make it a liveable and walkable city by connecting its residents to critical amenities within walking distance. The CoM has undertaken a wide range of programs to promote sustainable land use and increase the convenience of city dwellers. These include building green roofs, promoting green buildings, implementing water sensitive urban design (WSUD), and reducing the travel time of residents to access critical amenities, e.g. train stations. The city aims to ensure $95 \%$ its residents to live within $1 \mathrm{~km}$ of basic dayto-day service by 2020 [28].

\subsection{Climate change and energy}

The CoP environmental strategy aims to improve energy efficiency in city's operations, fleet and public spaces by supporting retrofits and encouraging improved energy performance initiatives in existing buildings[21]. It installed new energy efficient lighting in the Perth Exhibition and Convention Centre car park, which would halve the car park's energy consumption. The city has commenced a 10-year light emitting diode (LED) lighting upgrade plan on the council house ( $\mathrm{CoP}$ headquarters). The CoP has undertaken several energy efficiency improvement initiatives to reduce energy consumption from its own operations by $20 \%$ by 2021 . The city has invested $\$ 4$ million on installation of renewable energy and energy efficiency improvement projects. The CoP's emissions in 2006 was 0.96 million tCO2-e, which reduced to 0.91 million tCO2-e during $2014-15$. Under business-asusual (BAU) scenario, the city's emissions are expected to rise to 1.2 million tCO2-e by 2030 . However, the city aims to reduce its emissions by $30 \%$ by 2030 to 0.81 million tCO2-e [20].

The City of Melbourne plans to obtain $25 \%$ of the city's electricity from renewable sources by 2018 to increase energy resilience and reduce peak demand. Due to the fact that existing buildings of the city contribute to over $50 \%$ of the city's carbon emissions, the CoM has been delivering 1200 buildings, a voluntary information and education program to drive the retrofit of existing buildings for 5 years. The CoM is also an active member of the C40 Energy Efficiency Network [29]. In 2003, the CoM set an ambitious target for becoming a carbon neutral city by 2020 , and the city is on track to reducing its emissions by $10 \%$ by 2018 compared to the 2010-11 level.

\subsection{Biophilia}

Under "The City of Perth Urban Forest Plan" the CoP aims to protect existing trees, increase canopy cover from $19 \%$ to $30 \%$ by 2035 and prompting WSUD to offer the city dwellers a better liveability and to reduce the UHI effect in the city [23]. The CoM aims to increase the understorey vegetation in the municipality by increasing the canopy cover from currently $22 \%$ (about 60,000 ) to $44 \%$ by 2040 [15]. The city has taken several initiatives, such as adding trees, vertical greening and rainwater irrigation to cool the hot spots identified by thermal imagery $[30,31]$.

\subsection{Transport}

The cities have undertaken various initiatives to increase transport efficiency and reduce transport related GHG emissions. The CoP has developed a transport strategy to increase active (walking or cycling) journey to the city from current level of $8 \%$ to $15 \%$ by 2031, reduce car journey from $42 \%$ to $25 \%$, and increase the use of public transport from $50 \%$ to $60 \%$ during the same period [32] in order to reduce $30 \%$ emissions by 2030 [21]. In this regard, the CoP has already invested $\$ 0.5$ million invested on Cycle Plan to reduce energy consumption in transportation, and other works are underway. The transport strategy is to advocate that the public transport service (Transperth) operate with low emission vehicles [33]. The CoM aims to reduce the use of transport by its residents and dwellers by transforming the city to a walkable city by making the following changes by 2030 compared to 2009 level - increasing cycling from $4 \%$ to $10 \%$, reduce private car from $39 \%$ to $20 \%$, increase public transport from $36 \%$ to $40 \%$, and walking from $20 \%$ to $30 \%$ [33]. The "last kilometre freight plan" of the CoM aims to consolidate the freight delivery vehicles in such a way to have a $50 \%$ or lower occupancy of loading zones during peak time to lower traffic congestion in the city centre [34].

\subsection{Water}

The CoP has targets to reduce its scheme water use by $25 \%$, increase the use of alternative water sources, reduction of residential water use below $78 \mathrm{~kL}$ per person per year, increase water reuse in city properties, and support and foster WSUD [21] by 2030. The CoM is actively implementing WSUD by implementing a range of initiatives, for example, the concept of "fit-for-purpose", which aims to increase rainwater harvesting and water recycling, and reduce the use of potable water for purposes other than drinking. The CoM has made a significant progress since 2010 by reducing potable water consumption by $45.5 \%$ per resident, which equals a drop from $296 \mathrm{~L}$ to $161 \mathrm{~L}$ per day per resident. 
Table 2. Green Growth indicators with examples from the City of Perth and the City of Melbourne.

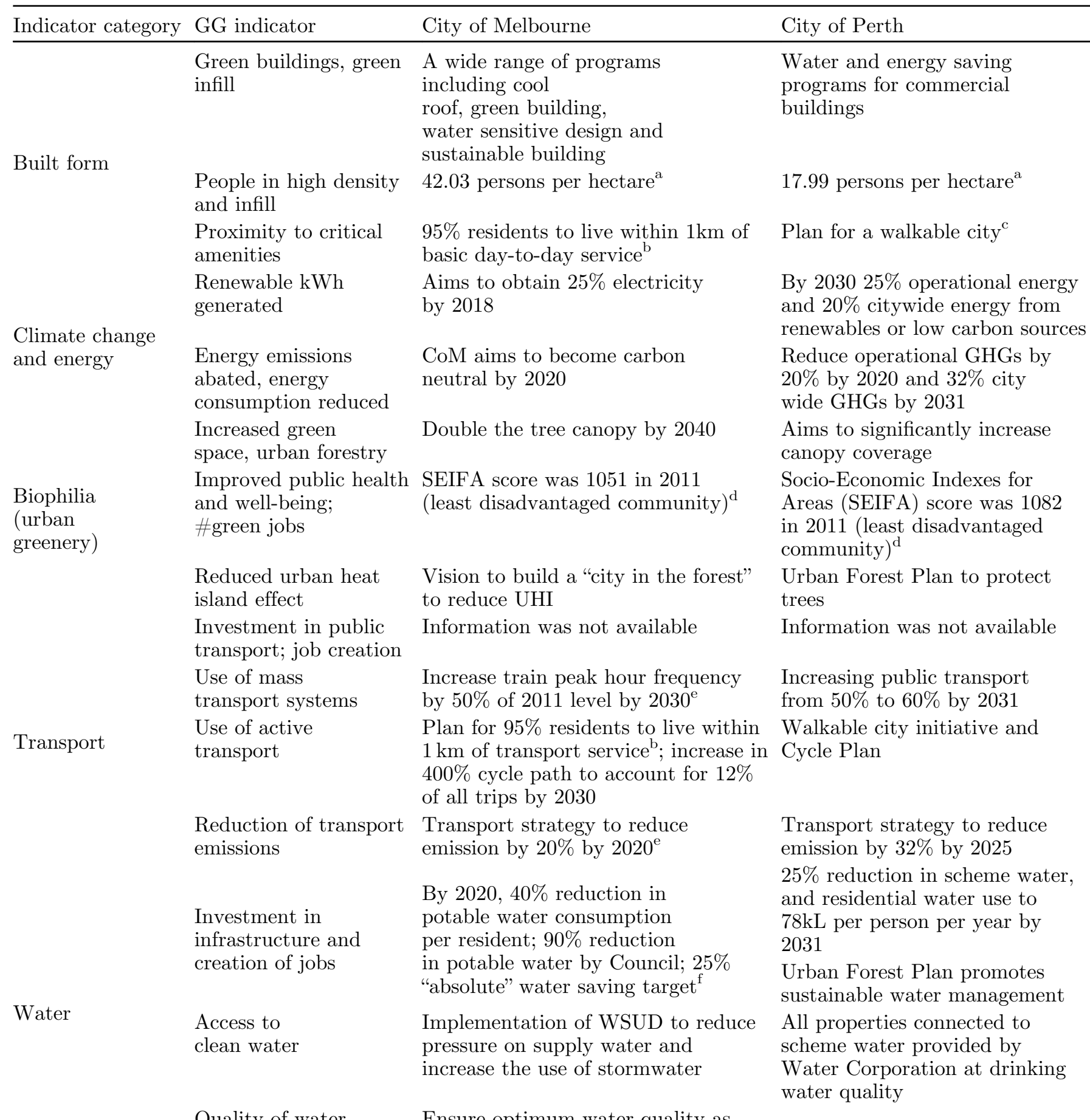

Quality of water Ensure optimum water quality as "fit-for-purpose"

Reduced waste generation, reduced landfill

Waste

Economic growth
Cleaner (waste free) environment

Safe disposal/ processing of waste
Diverted 23\% MSW from landfill in 2014-15, CoM aims to increase this share; emission from waste was 144,000 tCO2-e in 2012-13 ${ }^{\mathrm{g}}$

GLP of CoM was A $\$ 303.6$ million (2015-16); $18.3 \%$ of national $\mathrm{GDP}^{\mathrm{h}}$
Plans to divert $65 \%$ municipal solid waste (MSW) 70\% commercial and industrial waste, and $70 \%$ of construction and demolition waste from landfill by 2020

GDP was A $\$ 42$ billion (2015-16); $3 \%$ of national $\mathrm{GDP}^{\mathrm{h}}$ 
Table 2. (continued).

\begin{tabular}{llll}
\hline Indicator category & GG indicator & City of Melbourne & City of Perth \\
\hline $\begin{array}{l}\text { City level GDP } \\
\text { and city's GDP } \\
\text { as a share }\end{array}$ & & \\
$\begin{array}{l}\text { of national GDP } \\
\text { Carbon intensity }\end{array}$ & $\begin{array}{l}\text { Carbon intensity was } 64.40 \\
\text { of GDP }\end{array}$ & $\begin{array}{l}\text { COP's emission intensity } \\
\text { to reduce to } 55.29 \text { ktCO2-e }\end{array}$ & $\begin{array}{l}\text { in 2015 was 21.7 ktCO2-e } \\
\text { per AU } \$ \text { by } 2020\end{array}$ \\
& per & \\
\hline
\end{tabular}

Sources: ${ }^{\mathrm{a}}[37] ;{ }^{\mathrm{b}}[28] ;{ }^{\mathrm{c}}[39] ;{ }^{\mathrm{d}}[38] ;{ }^{\mathrm{e}}[40] ;{ }^{\mathrm{f}}[41] ;{ }^{\mathrm{g}}[36] ;{ }^{\mathrm{h}}[18]$.

\subsection{Waste}

The CoP manages its waste through a contracted service to the waste management authority Mindarie Regional Council (MRC), which sustainably processes household waste to divert a large amount from landfill. The CoP's waste strategy [35] aims to position the city as a "Waste Wise City" and sets targets to divert $65 \%$ municipal solid waste (MSW), 70\% commercial and industrial waste, and $70 \%$ of construction and demolition waste from landfill by 2020. The CoM's waste diversion rate from landfill in 2015 was $23 \%$, which compares to $45.5 \%$ of the state (Victoria) average and up to $50 \%$ in some other LGAs. However, the city has commenced a 10 point action plan to improve and increase the rate of waste diversion from landfill [36]. These include targeted awareness programs, which has reduced the amount of waste generation per household by $13 \%$ between 2009 and 2015. GHG emissions from the waste sector were 144,000 tCO2-e during 2012-13 and aims to reduce waste to landfill per resident by $5 \%$ by 2018 .

\subsection{Economic growth}

The Gross Regional Product (GRP) of the CoP in 2015-16 was A $\$ 42$ billion and represented $3 \%$ of national GDP [20]. The CoP's unemployment rate fell sharply from about $8 \%$ in 1996 to about $3.2 \%$ in 2008 and then rose to over $6 \%$ in 2016. The GDP per capita has been rising steadily from about $\mathrm{A} \$ 47,000$ in 1996 to about $\mathrm{A} \$ 74,000$ in 2016 [18]. The GDP of the CoM in 2015-16 was A $\$ 303.6$ billion and represented $18.3 \%$ of national GDP. Melbourne's $4.4 \%$ GDP growth rate was the highest since 2003-04. The CoM has been experiencing a steady economic growth since 2009, with an average annual growth in Gross Local Product (GLP) of $3.7 \%$ between 2009 and 2016 [18]. The city uses GLP as an economic factor, which is conceptually the same as GDP and GRP, and is a measure of the market value of all final goods produced in a specified region and over a given time period [27].

\section{Discussion}

Section 3 shows that cities offer an effective setting for the implementation GG. Table 2 compares GG of two case study cities by comparing data and information along the proposed indicators. It can be seen from the table that the City of Melbourne is executing many strategies and projects in order to transform the city into a zero-carbon city.

The case study cities are performing well in some of the indicator areas, e.g. biophilia (demonstrated by the large Socio-Economic Indexes for Areas (SEIFA) scores), transport, energy and climate change. Figure 1 presents a comparison of GLP (in billion A\$), and emission intensity (emissions per unit of GLP) for both BAU and the same under the carbon neutral plan by 2020 for the CoM. The figure indicates that under $\mathrm{BAU}$, the emission rises at a similar rate with the GLP, which does not satisfy the concept of GG (decoupling emission intensity from the economic growth). However, if the CoM is able to successfully achieve the emission reduction as targeted in the 2020 carbon neutral plan, the emissions will be decoupled from the economic growth. This will then appropriately respond to the key concept of GG, however, achievements will also need to be made along the other indicators. The CoP uses GRP as the economic indicator. Based on CoP's GRP of A $\$ 42$ billion (in 2015), the emission intensity was $21.7 \mathrm{ktCO} 2$-e per $\mathrm{A} \$$ billion GRP. Both the cities have been found to focus on improving green spaces, improve the walkability in the city and revamping the transport system to increase the use of public transport. However, while the CoP is still at the stages of policy and plan development, the CoM has implemented a range of programs and activities, and the results have started to appear. While the CoM is performing higher than the CoP in most indicator areas, its performance has not been very satisfactory in the waste sector. The CoP has been able to divert significant amount of waste from landfill and has increased the rate of recycling, however, the CoM's waste diversion from landfill has been low with $23 \%$ diversion rate, compared to $45.5 \%$ of its state level rate.

While the cities are measuring and recording a large amount of data and information in relation to energy, environment and sustainability, there is a lack of quantitative data in some areas that are important to assess the GG performance. For example, the CoP aims to develop a walkable city, but it does not provide any quantitative information in relation to the target for this. Another area in the $\mathrm{CoP}$ is the increase in canopy coverage where the forest cover as a percent of total land area would be more appropriate. Therefore, an alignment of data 
measurement and recording systems with the proposed indicators would improve the quality of performance assessment in future.

\section{Conclusions}

The GG in cities indicators that are proposed in this paper have been derived from the set of indicators for cities as suggested by the OECD. Indicators that are in use in different cities around the world also have been taken into consideration. Lastly, the choice of indicators that have been proposed for Australian cities has been based on the regulatory framework of Australian cities, as well as the types of data and information that are commonly measured and recorded at city level have also been considered. The proposed indicator set has been applied to two Australian capital cities - the City of Melbourne and the City of Perth to validate the suitability of these indicators to Australian cities, and to assess how these cities are performing in relation to GG. It was found that not all the indicators are applicable to Australian cities due mainly to the regulatory control in areas such as industry sector. Also, some indicators, such as the parentage of population with access to electricity, are not worth measuring because the entire population in Australia has access to electricity.

The two cities were found to be performing well in some areas, particularly in biophilia, climate and energy, water, waste and transport. However, there is a need for data availability along the proposed set of indicators. The CoM's emission intensity is seen to have been rising along with the economic growth, however, the if the city's plan to achieve emission reduction by 2020 is achieved, the emission would be decoupled from the economic growth, which would adequately respond to the key concept of GG. It is observed that while cities are performing well in some areas, the performance could not be measured along the entire spectrum of GG due to the limited availability of quantifiable data. The cities need to align their programs and policies, and most importantly the data measurement and recording systems, with the proposed indicators to be able to successfully implement and measure the GG.

Authors acknowledge the funding for conducting this research from school of Engineering and Information Technology of Murdoch University. Dr. Anisuzzaman and Dr. Urmee also acknowledge Hanse-Wissesschaftskolleg, Germany for initiating this research.

\section{References}

1. Imperatives, S., Report of the World Commission on Environment and Development: Our Common Future (United Nations, Oslo, 1987)

2. P. Newman, I. Jennings, Cities as Sustainable Ecosystems (2012), Available from: https://islandpress.org/book/citiesas-sustainable-ecosystems (last consulted on: 2017/16/07)

3. UN HABITAT, Economic Role of Cities (United Nations Human Settlements Programme, Nairobi, 2012)

4. OECD, Towards Green Growth (OECD Publishing, Paris, France, 2011)
5. OECD, Green Growth in Cities (OECD Publishing, Paris, France, 2013)

6. OECD, What is Green Growth and How Can it Help Deliver Sustainable Development? (OECD Publishing, Paris, France, 2015), Available from: http://www.oecd.org/green growth/whatisgreengrowthandhowcanithelpdeliversustaina bledevelopment.htm (last consulted on: 2015/28/09)

7. OECD, Green Growth in Stockholm, Sweden (OECD Publishing, Paris, France, 2013)

8. OECD, Green Growth in Kitakyushu, Japan (OECD Publishing, Paris, France, 2013)

9. R. Jones, B. Yoo, Korea's Green Growth Strategy: Mitigating Climate Change and Developing New Growth Engines (OECD Publishing, Paris, 2011)

10. L. Kamal-Chaoui, M. Plouin, Cities and Green Growth: Case Study of the Paris/Ile-de-France Region (OECD Publishing, Paris, 2012)

11. City of Sydney, Town Hall House Trigeneration (2016), Available from: http://www.cityofsydney.nsw.gov.au/vi sion/towards-2030/sustainability/carbon-reduction/trigen eration (last consulted on: 2016/06/05)

12. City of Perth, Towards an Energy Resilient City: Strategic Directions Paper (2016)

13. K. Rogers, Biophilia Hypothesis|Britannica.com, Encyclopedia Britannica (2017), Available from: https://www.britann ica.com/science/biophilia-hypothesis (last consulted on: 2017/10/07)

14. P. Newman, Biophilic urbanism: a case study on Singapore, Aust. Plan. 51, 47 (2014)

15. City of Melbourne, Melbourne's Urban Forest (2015), Available from: http://www.melbourne.vic.gov.au/SiteCol lectionDocuments/urban-forest-infographic.pdf (last consulted on: $2017 / 14 / 07$ )

16. L. Kamal-Chaoui, F. Grazi, J. Joo, M. Plouinm, The Implementation of the Korean Green Growth Strategy in Urban Area (OECD Regional Development, Working Papers 2011/02, OECD, Paris, 2011)

17. City of Perth, Transport Strategy (2016)

18. SGS, Australian Cities Accounts 2015-16 (2016)

19. SoE (State of the Environment Committee), Australia State of the Environment (Australian Government, Department of Sustainability, Environment, Water, Population and Communities, 2011)

20. City of Perth, Perth City Snapshot 2016 (Australian Capital Territory, 2600, Australia, 2016)

21. City of Perth, Environment Strategy (2016), p. 25

22. City of Perth, City of Perth Cycle Plan 2029. Available from: https://www.perth.wa.gov.au/planning-development/city-ini tiatives/city-perth-cycle-plan-2029, accessed on: 2017/23/01

23. CoP, Urban Forest 2016-2036 (2016)

24. ABS, Australian Bureau of Statistics (2017), Available from: http://stat.abs.gov.au/itt/r.jsp?RegionSummary\&region=2 GMEL\&dataset=ABS_REGIONAL_ASGS\&geoconcept $=$ REGION\&datasetASGS $=$ ABS REGIONAL ASGS\&data setLGA $=$ ABS_NRP9_LGA\&regionLGA $=$ REGION\&regio nASGS=REGION (last consulted on: 2017/16/07)

25. City of Melbourne, Zero Net Emissions - City of Melbourne (The City of Melbourne, Melbourne, Australia, 2014)

26. City of Melbourne, Submission to Victoria's Renewable Energy Roadmap (2015) 
27. City of Melbourne, Key Indicators - City of Melbourne Economic Profile (2017), Available from: http://melbourne. geografia.com.au/ (last consulted on: 2017/15/07)

28. Victoria Walks, Plan for a Walkable Melbourne (2013)

29. City of Melbourne, Setting Australia's Post 2020 Targets on Greenhouse Gas Emissions (2015), Available from: http:// www.melbourne.vic.gov.au/sitecollectiondocuments/submis sion-setting-aus-post-2020-targets-greenhouse-emissions20apr2015.pdf (last consulted on: 2017/14/07)

30. City of Melbourne, City of Melbourne Urban Water: Godfrey Street Greening, City of Melbourne Urban Water (2010), Available from: http://urbanwater.melbourne.vic.gov.au/ projects/greening-projects/godfrey-street-greening-project/ (last consulted on: 2017/15/07)

31. City of Melbourne, Green Facade at Fitzroy Gardens Visitor Centre, City of Melbourne Urban Water (2014), Available from: http://urbanwater.melbourne.vic.gov.au/projects/ greening-projects/green-facade-at-fitzroy-gardens-visitorcentre/ (last consulted on: 2017/15/07)

32. City of Perth, Transport Strategy
33. City of Melbourne, Bicycle Plan 2016-2020 (2016), Available from: http://www.melbourne.vic.gov.au/parking-and-trans port/cycling/Pages/bicycle-plan.aspx (last consulted on: 2017/14/07)

34. City of Melbourne, Last Kilometre Freight Plan (2016)

35. City of Perth, Waste Strategy 2014-2024+ (2013)

36. City of Melbourne, Waste and Resource Recovery Plan 2015$18(2015)$

37. IDCommunity, City of Perth Community Profile (2016), Available from: http://profile.id.com.au/perth (last consulted on: $2017 / 15 / 07)$

38. ABS, SEIFA by Local Government Area (LGA) (2017), Available from: http://stat.data.abs.gov.au/Index.aspx? DataSetCode=ABS_SEIFA_LGA (last consulted on: 2017/15/07)

39. City of Perth, Our Walkable City|City of Perth (2017), Available from: https://www.perth.wa.gov.au/planning-de velopment/city-initiatives/our-walkable-city (last consulted on: $2017 / 10 / 07)$

40. City of Melbourne, Transport Strategy 2012 (2012)

41. City of Melbourne, WSUD Guidelines (2006)

Cite this article as: Tania Urmee, Martin Anda, Anna Chapman, Md. Anisuzzaman, Green Growth in cities: two Australian cases, Renew. Energy Environ. Sustain. 2, 43 (2017) 